\title{
USE OF ALTERNATIVE AND COMPLEMENTARY MEDICINE IN PATIENTS WITH MALIGNANT DISEASES IN HIGH-VOLUME CANCER CENTER AND FUTURE ASPECTS
}

\author{
Davor Kust ${ }^{1}$, Ivan Šamija ${ }^{1}$, Jasmina Marić-Brozić ${ }^{1}$, Branka Svetec $^{1}$, Marija Miletić ${ }^{1}$, \\ Gordana Mamić 2 , Ante Bolanča ${ }^{1}, Z_{\text {vonko Kusić }}{ }^{1}$ and Ana Fröbe ${ }^{1}$
}

${ }^{1}$ Clinical Department of Oncology and Nuclear Medicine, ${ }^{2}$ Clinical Department of Hematology, Sestre milosrdnice University Hospital Center, Zagreb, Croatia

\begin{abstract}
SUMMARY - Usage of complementary and alternative medicine (CAM) is steadily increasing over the last decades, gaining medical, economic and sociological importance. The aim of the present study was to assess the use of complementary and alternative therapies in cancer patients. A crosssectional, descriptive survey design was used to collect data through an anonymous questionnaire. A total of 267 patients were included in the study. The prevalence of CAM use among cancer patients in this study was $60.3 \%$. It was found that 61 heterogeneous CAM therapies were used, the most popular among patients being naturopathy/folk medicine. In multivariate logistic regression analysis, independent predictors of CAM use were high income, divorced status, female sex and younger age. In conclusion, considering the fact that a large proportion of patients used at least one CAM approach, we need to continue our efforts to improve the patient-oncologist communication in order to deliver most reliable information to patients and to better understand the possible standard medicine-CAM interactions. According to results of the latest studies, CAM therapies that help manage pain, nausea, fatigue, anxiety, and other symptoms should be integrated into the patient overall care.
\end{abstract}

Key words: Alternative medicine; Cancer; Complementary medicine; Oncology; Croatia

\section{Introduction}

Complementary and alternative medicine (CAM) has been defined as "any diagnosis, treatment or prevention that complements mainstream medicine by contributing to a common whole, by satisfying a demand not met by orthodoxy, or by diversifying the conceptual framework of medicine"1. Additionally, some of these therapies are developed not to complement but to substitute the mainstream Western medicine, thus being 'alternative'. This definition includes a large variety of behavioral techniques and clinical ap-

Correspondence to: Davor Kust, $M D$ PhD, Clinical Department of Oncology and Nuclear Medicine, Sestre milosrdnice University Hospital Center, Vinogradska c. 29, HR-10000 Zagreb, Croatia E-mail: davor.kust@gmail.com

Received May 18, 2016, accepted September 28, 2016 proaches, including special diets, naturopathy, homeopathy, manipulative and psychological therapy, and many others. A common feature of all these techniques and approaches is that their effectiveness is still unproven, since no large clinical trials were conducted, although sellers of these products and promoters of alternative lifestyle, as well as some of the patients claim that they successfully treat cancer. Some success has been achieved in relieving cancer symptoms and lowering toxicity of standard treatment, such as management of chemotherapy-related nausea and vomiting with acupuncture, and pain relief with self-hypnosis, massage or acupuncture ${ }^{2,3}$.

Regardless of the lack of definitive scientific evidence for CAM, its popularity increases steadily over time, gaining medical, economic and sociological im- 
portance, especially when high cost of many of these therapies is taken into account ${ }^{4}$. It is estimated that CAM is used by $30 \%-40 \%$ of cancer patients in developed countries, although some studies report a prevalence as high as $64 \% \%^{4,5}$. Although the reasons for the current high popularity of these alternative treatments are complex and not fully understood, desperation, the need to do 'everything that can be done', specific patient beliefs about medicine, as well as specific social context and cultural differences could be recognized as motives $^{6}$. Also, the role of social media is of great importance, mainly in negative sense, since unverified and incorrect information is sometimes published, in order to expand the scope and popularity of CAM.

This is the first study conducted in Croatia, a recent European Union member, on the status of CAM in cancer patients. The aim of the study was to assess the use of complementary and alternative therapies in cancer patients in Croatia, using the same measurement tool and the same definition of CAM. Asking the patient about the use of CAM is important, since most of the cancer patients using alternative medicine also attend oncologists. There is a possibility of drug interactions and unexplainable side effects that may not be correctly interpreted due to the physician's ignorance about the whole spectrum of therapy in a particular patient.

\section{Patients and Methods}

A cross-sectional descriptive survey design was used to collect data through an anonymous questionnaire about CAM therapies, from October 2014 to October 2015. The study was conducted at a highvolume cancer center, where not only local patients but also those from all over the country are referred at some point of their disease for diagnostics, treatment and/or follow up. Investigators had full access to the patient medical records, and in the case of any unclear medical information regarding patients from other institutions, the leading physician was contacted. The questionnaire was designed in the mother language and the investigator was present during filling out the questionnaire to prevent any possible misunderstanding. The study was conducted in accordance with ethical standards set by the institutional Ethics Committee and the Helsinki Declaration from 1975, as revised in 1983. An informed consent was obtained from all participants before their enrollment in the study. Included patients were adults with a histopathologic diagnosis of cancer, either metastatic or non-metastatic, aware of their diagnosis, able to understand the questions, and free from any condition that would make completing the questionnaire inappropriate or overburdening. The questionnaire was developed by the authors themselves. Patients were asked about demographic data (gender, age, marital status, education, household income) and their personal experience with CAM (what CAM therapy the patient used, reasons for using, satisfaction and perceived effectiveness [on a 0-10 scale, with higher scores indicating higher levels of satisfaction or perceived effectiveness], sources of information or recommendation, consulting with their leading physician/oncologist about CAM use and potential interactions with the standard cancer treatment, time of commencement of CAM and the length of its use [in the case of current use, duration of treatment was calculated according to the day of enrollment in the study], their recommendation to other patients, the side effect profile and monthly cost of CAM therapy). CAM therapies and procedures were divided into 13 subgroups, as follows: 1 ) special diets and food supplements (excluding vitamins and minerals in this subgroup); 2) medicinal herbs; 3) medicinal fungi; 4) naturopathy and folk medicine; 5) medicinal teas; 6) vitamins and minerals; 7) homeopathy; 8) specific dietary supplements; 9) acupuncture; 10) applied kinesiology and yoga; 11) manipulative therapy (massage, reflexology, and craniosacral therapy); 12) mindbody intervention (spiritual therapy, healing, and energy therapy); and 13) psychological therapy (hypnosis, meditation, and relaxation techniques). Clinical data (site of primary cancer, stage of the disease, standard treatments received previously and current standard treatment) were collected directly from the patient medical records. Patients who did not report past or current use of CAM were also included in the study in order to evaluate the extent of CAM use among cancer patients.

\section{Statistical analysis}

Statistical significance of association between the use of CAM and other nominal categorical variables was determined by $\chi^{2}$ test. Statistical significance of association between the use of CAM and ordinal cate- 
gorical variable was determined by $\chi^{2}$ test for trend. Statistical significance of association between the use of CAM and numerical variables was determined by Mann-Whitney U test. Multivariate logistic regression analysis was performed to asses which variables predict CAM use, and all variables were included in the analysis. The analysis was performed using MedCalc (version 10.4.0.0, MedCalc Software bvba, Mariakerke, Belgium) and $p$ value of $\leq 0.05$ was considered statistically significant.

\section{Results}

All of the approached patients agreed to participate and gave their informed consent, and a total of 267 patients were included in the study. The mean follow up period was 26 (median=12; range $=2-228$ ) months and the mean patient age 61.4 (median=61; range $=33-83$ ) years. The patients having used CAM (median age 60 years) were significantly younger than the patients that did not use CAM (median age 64 years) (Mann-Whitney U test, $\mathrm{z}=4.98, \mathrm{p}<0.0001$ ). The number of male and female patients was almost equal, $134(50.2 \%)$ and 133 (49.8\%), respectively. Women (67\%) were more likely to use CAM than men (53\%) $\left(\chi^{2}\right.$ test $\left.=4.31, p=0.038\right)$. Basic demographic data and patient clinical characteristics are shown in Tables 1 and 2. There was significant association between marital status and the use of CAM ( $\chi^{2}$ test $\left.=13.53, \mathrm{p}=0.004\right)$. Eighty-three percent of divorced, $62 \%$ of married, $50 \%$ of single never married, and $34 \%$ of widowed patients reported using CAM. Also, there was a significant trend of increase in the proportion of patients using CAM with increasing education level $\left(\chi^{2}\right.$ test for trend $=6.33, p=0.012)$ and with increasing income $\left(\chi^{2}\right.$ test for trend=19.88, $\mathrm{p}<0.0001)$. CAM was used by $72 \%$ of patients with university education, $59 \%$ with secondary education and 50\% with only primary education. Results regarding income were similar, showing that $94 \%$ of CAM users had high income $(>800 €)$, $61 \%$ average income and 50\% low income $(<400 €)$. There was no association between the stage of disease and proportion of patients using CAM $\left(\chi^{2}\right.$ test $=5.83$, $\mathrm{p}=0.12)$. There was significant association between the type of cancer and CAM use $\left(\chi^{2}\right.$ test $\left.=50.07, \mathrm{p}<0.0001\right)$. Most of the patients, i.e. 129 (48.3\%) patients, had gastrointestinal cancer (61 colon cancer, 32 rectal cancer, 21 gastric cancer, 7 esophageal cancer, 3 anal can-
Table 1. Demographic data on study patients $(N=267)$

\begin{tabular}{|l|l|}
\hline Category & $\mathrm{n}(\%)$ \\
\hline Marital status & \\
Married & $205(76.8 \%)$ \\
Single (never married) & $10(3.7 \%)$ \\
Divorced & $23(8.6 \%)$ \\
Widowed & $29(10.9 \%)$ \\
\hline Education & \\
Elementary school & $54(20.2 \%)$ \\
Secondary school & $145(54.3 \%)$ \\
University/PhD & $68(25.5 \%)$ \\
\hline Household income & $126(47.2 \%)$ \\
Low $(\leq 400 €)$ & $106(39.7 \%)$ \\
Average $(400-800 €)$ & $35(13.1 \%)$ \\
High $(\geq 800 €)$ & \\
\hline
\end{tabular}

cer, 3 bile duct cancer, and 2 liver cancer). Primary tumor sites in other patients were as follows: breast in 27 (10.1\%); skin and eye (melanoma) in 26 (9.7\%); ovary in 12 (4.5\%); thyroid in 11 (4.1\%); prostate and lung in $9(3.4 \%)$ patients each; lymph nodes in 7 (2.6\%); pleura and brain in $4(1.5 \%)$ patients each; and larynx, urinary bladder, testis, parathyroid gland, penis, oropharynx, nasopharynx and adrenal gland in $2(0.7 \%)$ patients each. In 11 (4.1\%) patients, the primary tumor site was unknown. Patients treated with chemotherapy and/or targeted therapy were significantly more likely to use CAM ( $\chi^{2}$ test=13.13, $\mathrm{p}=0.0003$ ), whereas those treated with radiotherapy were significantly less likely to use CAM ( $\chi^{2}$ test=7.28, $\left.\mathrm{p}=0.007\right)$. There was no association between hormonal therapy and use of CAM $\left(\chi^{2}\right.$ test $\left.=3.71, \mathrm{p}=0.054\right)$.

Considering CAM use, statistical analysis showed that 161 of $267(60.3 \%)$ patients included in the study used some form of CAM. Thirteen (4.9\%) patients reported using special diets and food supplements including omega-3 fatty acids, mixed fruit juices, and sugar-free diet (with the exception of vitamins and minerals); 53 (19.9\%) patients used medicinal herbs (including turmeric, aloe vera, noni (Morinda citrifolia), various herbal formulations, stone root, spelt, cannabis, mistletoe, mixed herbal liquid preparations, parsley, and ginger); 10 (3.7\%) patients used medicinal fungi (including Tibetan milk mushroom, Cordyceps fungi, maitake, shiitake, lingzhi, almond and oyster mushroom); 108 (40.4\%) patients implemented naturopathy and folk medicine (including mixed beet-carrot-apple juice, aronia, blackberry wine, linseed, hash, 
Table 2. Disease stage and standard oncologic treatment received $(N=267)$

\begin{tabular}{|l|l|}
\hline Category & $\mathrm{n}(\%)$ \\
\hline Stage of disease: & $37(13.9 \%)$ \\
I & $33(12.4 \%)$ \\
II & $74(27.7 \%)$ \\
III & $123(46.1 \%)$ \\
IV & \\
\hline Standard oncologic therapy received: & $27(10.1 \%)$ \\
Chemotherapy alone & $31(11.6 \%)$ \\
Surgery alone & $9(3.4 \%)$ \\
Chemotherapy + radiotherapy & $73(27.3 \%)$ \\
Chemotherapy + surgery & $12(4.5 \%)$ \\
Radiotherapy + surgery & $8(3 \%)$ \\
Chemotherapy + radiotherapy + targeted therapy & $43(16.1 \%)$ \\
Chemotherapy + radiotherapy + surgery & $38(14.2 \%)$ \\
Chemotherapy + targeted therapy + surgery & $11(4.1 \%)$ \\
Radiotherapy + endocrine therapy + surgery & $15(9.3 \%)$ \\
Other combinations & \\
\hline
\end{tabular}

Table 3. Reasons and motives for CAM use (N=161)

\begin{tabular}{|l|l|}
\hline Category & $\mathrm{n}(\%)$ \\
\hline Boosting the immune system & $71(44.1 \%)$ \\
Convinced by friends and/or family members & $18(11.2 \%)$ \\
Treatment of the main disease & $18(11.2 \%)$ \\
Prevention of disease dissemination & $15(9.3 \%)$ \\
Improvement of blood findings & $14(8.7 \%)$ \\
Reduced toxicity of standard oncologic therapy & $11(6.8 \%)$ \\
No specific reason & $10(6.2 \%)$ \\
Symptomatic treatment & $7(4.3 \%)$ \\
Detoxication & $5(3.1 \%)$ \\
Desperation & $2(1.2 \%)$ \\
\hline
\end{tabular}

lavender and black-cumin oil, royal jelly, bee pollen, sodium bicarbonate, propolis, honey, almond, and alcohol-honey preparations); 17 (6.4\%) patients took medicinal teas (including mixed herbal, lapacho (taheebo), teucrium and Siberian algae tea); 10 (3.7\%) patients used vitamins and minerals (including multivitamin supplements, and vitamin C); 9 (3.4\%) patients applied homeopathy (including drug containing peptides extracted from the blue scorpion venom, and zinc); 54 (20.2\%) patients used specific dietary supplements (products containing beta-glucan, amygdalin, arabynoxylan, soursoup, chlorophyll, quinones, and/or fungal extracts); none of the patients underwent acupuncture; 5 (1.9\%) patients practiced applied kinesiol- ogy and yoga; 3 (1.1\%) patients underwent manipulative therapy (including massage, reflexology, and craniosacral therapy); 2 (0.7\%) patients underwent mind-body interventions (including spiritual therapy, healing, and energy therapy); and 3 (1.1\%) patients used some form of psychological therapy (including hypnosis, meditation, and relaxation techniques). In total, more than 60 different CAM treatments were used. The majority of patients used more than one CAM therapy, and the mean number of CAM per patient was 2.3 (median=2; range $=1-7$ ).

When asked about the reasons and motives for CAM use, most of the patients reported boosting their immune system, as shown in Table 3. In this study, pa- 


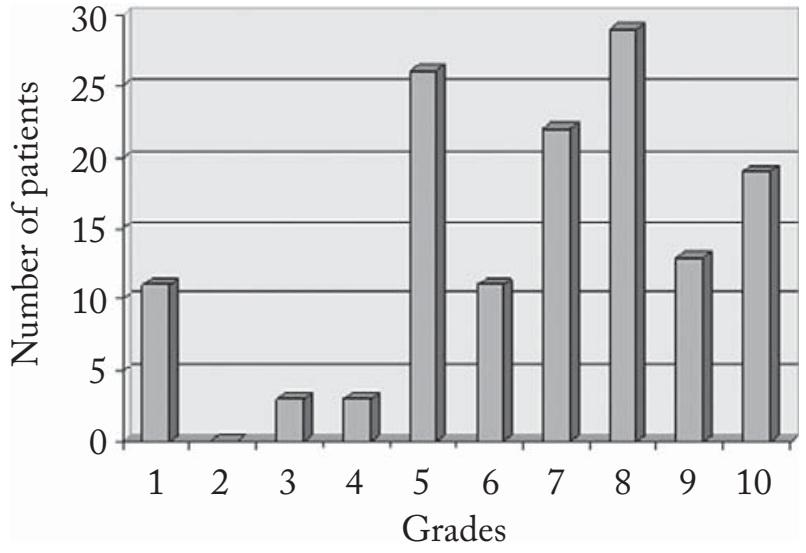

Fig. 1. Satisfaction with CAM treatment: patients were generally well satisfied with CAM therapies, even if they did not see any objective effects (1 - not satisfied at all; 10 - fully satisfied).

tients were generally very satisfied with the effectiveness of CAM according to their feedback, as shown in Figure 1 (mean satisfaction score 6.7, median satisfaction score 7). However, 139 (52.1\%) patients could not decide whether to recommend CAM use to other cancer patients, 112 (41.9\%) patients stated they would do it, while $6(2.2 \%)$ patients would not. The sources of information on CAM are shown in Table 4. Around two-thirds of patients (107 or $66.5 \%$ of them) using CAM did not talk about alternative therapies with their oncologist, while 54 (33.5\%) patients admitted using CAM to the oncologist. Among patients having admitted using CAM, there were significantly more female $(37 / 89 ; 41.6 \%)$ than male $(17 / 72 ; 23.6 \%) \mathrm{pa}^{-}$ tients $\left(\chi^{2}=4.98, \mathrm{p}=0.026\right)$. Forty-four out of $161 \mathrm{pa}-$ tients $(27.3 \%)$ using CAM had started using it right after the surgery, $33(20.5 \%)$ right after the diagnosis, 29 (18\%) during chemotherapy, 21 (13\%) at the beginning of chemotherapy, 15 (9.3\%) after disease progression or recurrence, $10(6.2 \%)$ before the diagnosis of cancer, 5 (3.1\%) after completion of chemotherapy, 2 (1.2\%) during radiotherapy, and 2 (1.2\%) during follow up. None of the patients started using CAM during endocrine therapy or immunotherapy. The mean duration of CAM therapy was 7.81 (median=4; range $=0.25-72$ ) months. The vast majority of patients did not observe any side effects of CAM and tolerated it well. Four (2.5\%) patients reported constipation, 3 (1.9\%) drowsiness, 3 (1.9\%) vomiting, 2 (1.2\%) diarrhea, and $2(1.2 \%)$ burning sensation in the eyes. Thir-
Table 4. Sources of information about CAM used by our patients $(N=161)$

\begin{tabular}{|l|l|}
\hline Category & $\mathrm{n}(\%)$ \\
\hline Friends and/or family members & $66(41 \%)$ \\
Other patients & $33(20.5 \%)$ \\
Internet & $25(15.5 \%)$ \\
General practitioner & $12(7.5 \%)$ \\
Pharmacist & $11(6.8 \%)$ \\
Books, newspapers & $7(4.3 \%)$ \\
Television & $2(1.2 \%)$ \\
Alternative practitioner & $2(1.2 \%)$ \\
Unknown & $3(1.9 \%)$ \\
\hline
\end{tabular}

ty-seven (23\%) CAM users were aware of the potential interactions between the alternative and standard oncologic therapy, while in 124 (77\%) patients this problem was not addressed by medical professionals in contact with the patient. The average monthly cost of $\mathrm{CAM}$ per patient was $114 €$ (median=40; range= 0-1510).

In multivariate logistic regression analysis with demographic and clinical (type of cancer) variables included, independent predictors of CAM use were income more than $800 €(\mathrm{OR}=10.88,95 \%$ CI 2.43 48.80, $\mathrm{p}=0.002)$, divorced status $(\mathrm{OR}=3.95,95 \% \mathrm{CI}$ 1.26-12.37, $\mathrm{p}=0.019)$, female sex $(\mathrm{OR}=2.02,95 \% \mathrm{CI}$ $1.17-3.48, \mathrm{p}=0.012)$ and younger age $(\mathrm{OR}=0.95,95 \%$ CI $0.92-0.98, \mathrm{p}=0.0003$ ).

\section{Discussion}

In this study, the prevalence of CAM use among cancer patients was $60.3 \%$, which is in accordance with several previously conducted studies in adult population $^{4,5}$. In pediatric population, the rates are equally high, ranging from $32.7 \%$ in the UK to $84 \%$ in the $\mathrm{USA}^{7,8}$. Significant variability of the prevalence reported in different studies (30\%-64\%, or even more) could be explained by population differences, as well as the lack of specificity, inconsistent definitions, and patient understanding of what CAM is. Additionally, the reported numbers refer to patients treated with standard cancer therapy and using CAM as supplementary treatment, while the patients using CAM as the only treatment modality are usually not included in these studies, suggesting that the prevalence of CAM use 
among cancer patients could be even higher. Also, the patient openness to talk about CAM use is obviously a very important factor. One of the reasons for the reported increased use of CAM could be that patients are more comfortable to talk about this topic than before, probably partly influenced by the wider presence and coverage of CAM in social media, which is in accordance with our results, suggesting that CAM users were significantly younger than nonusers. However, personal and cultural differences, fear of developing conflict of opinion with health care team, shame, and possibly some other unrecognized factors could cause non disclosure of all the types of treatment used to physician. An additional cause for not admitting CAM usage could be timing of interview regarding their disease, as patients that are interviewed after disease has been put under control could possibly be more open to admit their behavior during treatment than those that are still depending on treatment outcome. In a large European survey of CAM use, the authors have reported that a significant number of participants did not want their healthcare team to know about their use of $\mathrm{CAM}^{9}$. In the present study, most of the patients $(66.5 \%)$ did not admit using CAM to their leading oncologist. However, this may be caused by inadequate patient-physician communication.

When asked to participate in the study, all patients agreed to it. They all were very open and interested in the study, asked questions about CAM they used, and a bond and trust were developed between the patient and the physician who was supervising the questionnaire completion. To encourage open communication about CAM use by patients, oncologists should be familiar with the most popular remedies and know where to find reliable information for themselves and for their $\mathrm{pa}^{-}$ tients ${ }^{10}$. The cost could also be one of the reasons for deciding to use or not to use CAM, since almost half of the patients included in the study had low income $(<400$ $€)$, and average cost of monthly CAM therapy was 114 $€$. Statistical analysis yielded correlation between higher income and higher CAM use.

It was found that 61 heterogeneous CAM therapies were used and the most popular among the patients were naturopathy/folk medicine (reported by $67.1 \%$ of CAM users), specific commercially available food supplements (33.5\%), and medicinal herbs (32.9\%), which is generally similar to the results of some previous studies ${ }^{11-13}$. It is interesting that none of the patients underwent acupuncture, according to several reports the most commonly used CAM modality worldwide ${ }^{14}$. It was probably due to the specific cultural way of life, which is also an important factor of the patient lifestyle ${ }^{15}$. Patients typically used more than one CAM therapy (on average 2.3 per patient), and two patients applied even 7 different CAM approaches at the time, which in turn complicates understanding of the potential benefits of the therapies administered. Although the patients using CAM may be at a risk of side effects and potential interactions with the main oncologic treatment, especially when several CAM therapies are used together, only $23 \%$ of the patients were aware of this fact. However, CAM therapy was generally well tolerated, and only several patients (8.7\%) reported side effects, including vomiting and diarrhea, which are often also caused by standard treatment, especially chemotherapy, concluding that even these small numbers may be exaggerated. On the other hand, several studies have reported the potential side effects of CAM, including allergic contact dermatitis and organ toxicity (including liver, kidneys and heart) associated with medicinal herbs, mechanical injuries and infections (including hepatitis and bacterial endocarditis) with acupuncture, as well as various nutritional deficiencies (especially in infants and small children given strict alternative diets). The authors suggest that some herbs may also have carcinogenic properties ${ }^{16}$.

Almost half of the patients had metastatic disease, characterized in most of the cases by poor prognosis. Although no relevant clinical data are available to date, CAM may have a role in increasing hope and optimism, and subsequent improvement in physical and psychosocial wellbeing. Some patients also believed that CAM could cure their disease, but most of them were more rational, as confirmed in some previous studies $^{9}$. In this study, the majority of CAM users reported boosting their immune system as the main reason for CAM therapies, while only 18 patients thought it could actually kill cancer cells. This is consistent with data suggesting that patients mostly used CAM after more aggressive therapeutic approaches, such as chemotherapy and surgery, while none of them started using CAM during endocrine therapy or immunotherapy. Interestingly, although inadequate physician-patient communication and dissatisfaction with some aspects of conventional health care may be contribut- 
ing factors to desperation, only two patients admitted that desperation was the reason for CAM use. A study by Burstein et al. investigating breast cancer patients showed that those patients that were more depressed and had greater fear of recurrence were more prone to using $\mathrm{CAM}^{17}$. In our study, divorced patients used CAM significantly more often than other groups of patients.

Even in the cases where there was no objective evidence for effectiveness, patients were subjectively generally very satisfied with CAM therapies (Fig. 1). This may lead to the conclusion that, although there is no strong scientific evidence to recommend CAM, physicians should not prohibit its use. This could be especially important in the palliative setting, when disease is incurable and maintaining the quality of life remains the main goal. Thus, health professionals should broaden their knowledge about CAM in order to provide complete and correct information to patients. In this study, the most common source of information about CAM was family and friends (41\%), other patients (20.5\%), and Internet (15.5\%). These sources are potentially very biased, not adjusted to the individual characteristics of the patient, and could even provide incorrect information ${ }^{18}$. Patients are obviously aware of this fact, and most of them could not decide whether to recommend CAM they used to other cancer patients. In contrast, only 12 of our patients got the information about CAM from their general practitioner, and 11 from their pharmacist.

In conclusion, considering the fact that a large proportion of patients used at least one CAM approach, we need to continue our efforts to improve patientoncologist communication and initiate research to determine the possible standard of medicine-CAM interactions, as well as the effectiveness of specific CAM approaches. Since it is estimated that cancer incidence will continue to rise, the uncertainties regarding CAM will become even more important and CAM users, if trends continue, even more numerous. Additionally, according to the available data, CAM therapies are used not only for malignant diseases, but for a vast number of different medical conditions as well ${ }^{19}$. As patients become more knowledgeable of these approaches, working with the practitioners from various disciplines will become an integral part of cancer patient care. To date, although extensive CAM use among cancer patients has been recognized, the impact of CAM on cancer patient survival and quality of life has been explored only sporadically. Thus, we need to broaden our understanding of the concepts of CAM by increased funding of CAM research. CAM therapies that help manage pain, nausea, fatigue, anxiety, and other symptoms should be integrated in the $\mathrm{pa}^{-}$ tient overall care.

\section{Learning points}

- the prevalence of CAM use among cancer patients is high, $60.3 \%$ in this study;

- a large number of heterogeneous CAM therapies are used by cancer patients, increasing the risk of the possible standard medicine-CAM interactions;

- considering the high prevalence of CAM use among cancer patients, we need to continue our efforts to improve patient-oncologist communication;

- effectiveness of the specific CAM approaches are still not well known;

- understanding the concept of CAM should be broadened by increased funding of CAM research; and

- CAM therapies that help manage pain, nausea, fatigue, anxiety, and other symptoms should be integrated in the patient overall care.

\section{References}

1. Ernst E, Resch KL, Mills S, et al. Complementary medicine - a definition. Br J Gen Pract. 1995;45:506.

2. Shen J, Wenger N, Glaspy J, et al. Electroacupuncture for control of myeloablative chemotherapy-induced emesis: a randomized controlled trial. J Am Med Assoc. 2000;284:2755-61.

3. Pan CX, Morrison RS, Ness J, Fugh-Berman A, Leipzig RM. Complementary and alternative medicine in the management of pain, dyspnea, and nausea and vomiting near the end of life. A systematic review. J Pain Symptom Manag. 2000;20:374-87.

4. Ernst E, Cassileth BR. The prevalence of complementary/alternative medicine in cancer. A systematic review. Cancer. 1998;83:777-82.

5. Richardson MA, Sanders T, Palmer JL, Greisinger A, Singletary SE. Complementary/alternative medicine use in a comprehensive cancer center and the implications for oncology. J Clin Oncol. 2000;18:2505-14, http://dx.doi.org/10.1200/ jco.2000.18.13.2505 
6. Ernst E, Willoughby M, Weihmayr TH. Nine possible reasons for choosing complementary medicine. Perfusion. 1995;11: 356-8.

7. Molassiotis A, Cubbin D. Thinking outside the box. Eur J Oncol Nurs. 2004;8:50-60, http://dx.doi.org/10.1016/S14623889(03)00054-1

8. Kelly KM, Jacobson JS, Kennedy DD, Braudt SM, Mallick M, Weiner MA. Use of unconventional therapies by children with cancer at an urban medical center. J Pediatr Hematol Oncol. 2000;22:412-6.

9. Molassiotis A, Fernadez-Ortega P, Pud D, et al. Use of complementary and alternative medicine in cancer patients: $\mathrm{a} \mathrm{Eu}-$ ropean survey. Ann Oncol. 2005;16:655-63, http://dx.doi. org/10.1093/annonc/mdi110

10. Cassileth BR, Deng G. Complementary and alternative therapies for cancer. Oncologist. 2004;9(1):80-9, http://dx.doi. org/10.1634/theoncologist.9-1-80

11. Oneschuk D, Fennell L, Hanson J, Bruera E. The use of complementary medications by cancer patients attending an outpatient pain and symptom clinic. J Palliat Care. 1998;14:21-6.

12. Jordan ML, Delunas LR. Quality of life and patterns of nontraditional therapy use by patients with cancer. Oncol Nurs Forum. 2001;28:1107-13.
13. Bernstein BJ, Grasso T. Prevalence of complementary and alternative medicine use in cancer patients. Oncology. 2001;15: 1267-72.

14. Carmady B, Smith CA. Use of Chinese medicine by cancer patients: a review of surveys. Chin Med. 2011;6:22, http://dx. doi.org/10.1186/1749-8546-6-22

15. Ginter E, Simko V. Recent data on Mediterranean diet, cardiovascular disease, cancer, diabetes and life expectancy. Bratisl Lek Listy. 2015;116(6):346-8, http://dx.doi.org/10.4149/ BLL_2015_065

16. Niggemann B, Gruber C. Side effects of complementary and alternative medicine. Allergy. 2003;58:707-16, http://dx.doi. org/10.1034/j.1398-9995.2003.00219.x

17. Burstein HJ, Gelber S, Guadagnoli E, Weeks JC. Use of alternative medicine by women with early-stage breast cancer. $\mathrm{N}$ Engl J Med. 1999;340(22):1733-9, http://dx.doi.org/10.1056/ NEJM199906033402206

18. Molassiotis A, Xu M. Quality and safety issues of web-based information about herbal medicines in the treatment of cancer. Complement Ther Med. 2004;12(4):217-27, http://dx.doi. org/10.1016/j.ctim.2004.09.005

19. Bašić Kes V, Cesarik M, Zadro Matovina L, et al. The role of complementary and alternative medicine in therapy of multiple sclerosis. Acta Clin Croat. 2013;52(4):464-71.

Sažetak

\section{UPOTREBA ALTERNATIVNE I KOMPLEMENTARNE MEDICINE U BOLESNIKA S MALIGNIM BOLESTIMA U VELIKOM ONKOLOŠKOM CENTRU I GLEDIŠTA NA BUDUĆNOST}

\section{Kust, I. Šamija, J. Marić-Brozić, B. Svetec, M. Miletic, G. Mamić, A. Bolanča, Z. Kusić i A. Fröbe}

Proširenost upotrebe komplementarne i alternativne medicine (KAM) u posljednjih nekoliko desetljeća u stalnom je porastu, dobivajući sve veće medicinsko, ekonomsko i sociološko značenje. Cilj ovoga istraživanja bio je procijeniti proširenost upotrebe KAM u onkoloških bolesnika u Hrvatskoj. Studija je dizajnirana kao presječno, deskriptivno, pregledno istraživanje te je provedena u obliku anonimnog upitnika. Istraživanje je provedeno na onkološkoj i hematološkoj klinici kliničkog bolničkog centra s velikim obrtajem onkoloških bolesnika. Ukupno 267 bolesnika koji su dali svoj informirani pristanak bilo je uključeno u studiju. Nakon statističke analize utvrđena je učestalost upotrebe KAM kod onkoloških bolesnika 60,3\%. Pokazalo se da je korišten ukupno 61 različit oblik KAM, a najpopularnija alternativna terapija među bolesnicima bila je naturopatija/narodna medicina. U multivarijatnoj logističkoj regresijskoj analizi nezavisni prediktori povezani uz korištenje KAM bili su visoka primanja, razveden/a stanje, ženski spol i mlađa dob. S obzirom na činjenicu da značajan udio bolesnika koristi barem jedan oblik KAM nužno je nastaviti djelovanje u smjeru poboljšanja komunikacije između bolesnika i onkologa te razmisliti o integraciji onih KAM terapija koje imaju pozitivan učinak u uklanjanju boli, mučnine, umora, anksioznosti i drugih simptoma u cjelokupnu onkološku skrb.

Ključne riječi: Alternativna medicina; Rak; Komplementarna medicina; Onkologija; Hrvatska 